\title{
Emended Description of Herbaspirillum; Inclusion of [Pseudomonas] rubrisubalbicans, a Mild Plant Pathogen, as Herbaspirillum rubrisubalbicans comb. nov.; and Classification of a Group of Clinical Isolates (EF Group 1) as Herbaspirillum Species 3
}

\author{
J. I. BALDANI, ${ }^{1}$ B. POT, ${ }^{2}$ G. KIRCHHOF,${ }^{3}$ E. FALSEN,${ }^{4}$ V. L. D. BALDANI, ${ }^{1}$ F. L. OLIVARES, ${ }^{1}$ B. HOSTE ${ }^{2}$ \\ K. KERSTERS, ${ }^{2}$ A. HARTMANN,${ }^{3}$ M. GILLIS, ${ }^{2 *}$ AND J. DÖBEREINER ${ }^{1}$ \\ EMBRAPA-CNPAB, Empresa Brasiliera de Pesquisa Agropecuaria-Centro Nacional de Pesquisa de Agrobiologia, Seropédica \\ 23851-970, Rio de Janeiro, Brazil ; Laboratorium voor Microbiologie, Universiteit Gent, B-9000 Ghent, Belgium ${ }^{2}$; GSF- \\ Forschungszentrum für Umwelt und Gesundheit, Institut für Bodenökologie, Neuherberg, D-85758 Oberschleissheim, \\ Germany ${ }^{3}$; and Department of Clinical Bacteriology, University of Göteborg, Göteborg, Sweden ${ }^{4}$
}

\begin{abstract}
[Pseudomonas] rubrisubalbicans, a mild plant pathogen, Herbaspirillum seropedicae, and EF group 1 strains (clustered by an immunological method) were investigated by a polyphasic approach with DNA-rRNA and DNA-DNA hybridizations and auxanography on 147 substrates. Our results show that they all belong to the genus Herbaspirillum. In addition to $\boldsymbol{H}$. seropedicae, two other species are described: Herbaspirillum rubrisubalbicans and a new unnamed species, Herbaspirillum species 3, containing mainly strains of clinical origin. The three species can be differentiated on the basis of their auxanographic features and DNA-DNA similarities. The type strain of $H$. rubrisubalbicans is NCPPB 1027 (=LMG 2286); representative strains of the third Herbaspirillum species are strains CCUG 189 (=LMG 5523), CCUG 10263 (=LMG 5934), and CCUG 11060 (=LMG 5321). It has been confirmed that $H$. rubrisubalbicans is an endophytic diazotroph. It colonizes the roots, the stems, and predominantly the leaves of sugarcane (Saccharum spp.), while Herbaspirillum seropedicae colonizes in large numbers many different species of the Gramineae. Both diazotrophic Herbaspirillum species could be differentiated with meso-erythritol and $N$-acetylglucosamine. Oligonucleotide probes based on partial sequences of the 23S rRNA of $H$. seropedicae and $H$. rubrisubalbicans (HS and HR probes, respectively), were constructed and used as diagnostic probes.
\end{abstract}

Herbaspirillum seropedicae, isolated from the roots and rhizosphere soil samples of various cereals, was originally thought to be a new species of the genus Azospirillum, because of its growth behavior in nitrogen-free semisolid medium (2). However, Baldani et al. (3) and Falk et al. (12) found that it belonged in the $\beta$-subclass of the Proteobacteria and created a new genus, Herbaspirillum, with a single species, $H$. seropedicae. Later it was shown that this species belonged to a rRNA cluster also containing [Pseudomonas] rubrisubalbicans, a group of strains of clinical origin, and Janthinobacterium lividum (16). The clinical isolates have been grouped in the so-called EF group 1 on the basis of their immunological relationships (13). J. lividum contains strictly aerobic motile bacteria commonly found in soil and water in temperate regions and producing violet colonies (32). $[P$.] rubrisubalbicans has been isolated from diseased cane leaves and has been described as the causative organism of mottled stripe disease (18). It has been shown that only some sugarcane genotypes are sensitive to the disease.

In 1991, Pimentel et al. (29) demonstrated that strains of [P.] rubrisubalbicans were able to grow and fix $\mathrm{N}_{2}$ in $\mathrm{N}$-free semisolid medium. Later, Baldani et al. (4) used the $\mathrm{C}_{2} \mathrm{H}_{2}$ reduction tests as well as incorporation of ${ }^{15} \mathrm{~N}_{2}$ to confirm that $H$. seropedicae and $[P$.] rubrisubalbicans are true diazotrophs. Both species also show a remarkable tolerance of higher sugar

${ }^{*}$ Corresponding author. Mailing address: Laboratorium voor Microbiologie (WE10V), Universiteit Gent, K.-L. Ledeganckstraat, 35, B-9000 Ghent, Belgium. Phone: 329264 5117. Fax: 3292645346. Electronic mail address: Moniek.Gillis@rug.ac.be. concentrations and are able to grow in up to $10 \%$ sucrose, although this carbon source is normally not used by Herbaspirillum spp. (4).

In this study, we performed a polyphasic taxonomic analysis with a large collection of strains belonging to $H$. seropedicae, $[P$.] rubrisubalbicans, J. lividum, and EF group 1.

\section{MATERIALS AND METHODS}

Media and methods of isolation. For the isolation of the two $\mathrm{N}_{2}$-fixing $\mathrm{Her}$ baspirillum spp., a modified $\mathrm{N}$-free semisolid $\mathrm{NFb}$ medium (10) was used at $\mathrm{pH}$ 5.8 and with $3 \times$ the phosphate concentration of $\mathrm{NFb}$ as well as omission of vitamins (4). The new medium (JNFb) was more selective for isolation of $H$. seropedicae and $H$. rubrisubalbicans. Serial dilutions of smashed soil, root, stem, and leaf samples were inoculated into $10-\mathrm{ml}$ vials containing $5 \mathrm{ml}$ of $\mathrm{JNFb}$ medium and incubated for 1 week at $32^{\circ} \mathrm{C}$. Fine white pellicles, very similar to Azospirillum spp. pellicles in classical NFb medium, were observed; cells of the white pellicles were examined under the microscope and were shown to be small, often slightly curved cells which move close to air bubbles. After an additional transfer and 24 to $48 \mathrm{~h}$ of growth in new JNFb medium, such cultures were streaked out on solid $\mathrm{NFb}$ medium containing $20 \mathrm{mg}$ of yeast extract per liter and $3 \times$ the bromothymol blue concentration of normal $\mathrm{NFb}$. On these plates, both diazotrophic Herbaspirillum spp. form small moist colonies with blue centers, much different from Azospirillum spp. colonies, which are white, dry, and curled. The isolation procedures for Herbaspirillum species 3 of mixed origin will be described elsewhere (14)

Strains. The strains used in this study are presented in Table 1. The EF group 1 organisms are of clinical origin and have been grouped before by one of us by an immunological technique (13).

DNA preparation. Crude DNA was prepared by the method of Marmur (23) DNA base composition. The mean $\mathrm{G}+\mathrm{C}$ contents were determined by the thermal denaturation method (9) and were calculated by the equation of Marmur and Doty (24), as modified by De Ley (5).

DNA-rRNA hybridizations. High-molecular-mass DNA was further purified by $\mathrm{CsCl}$ gradient centrifugation and fixed on cellulose nitrate filters (type SM 11358; Sartorius, Göttingen, Germany) as described previously (8). The amount of filter-fixed DNA was determined chemically (36). ${ }^{3} \mathrm{H}$-labeled rRNA from $H$. 
TABLE 1. Characteristics of the strains used in this study

\begin{tabular}{|c|c|c|c|c|c|}
\hline Name as received & Taxonomic position $^{a}$ & Strain no. ${ }^{b}$ & $\begin{array}{l}\text { Other strain } \\
\text { designation }^{b}\end{array}$ & $\begin{array}{l}\text { Received } \\
\text { from }^{b}\end{array}$ & $\begin{array}{c}\text { Source } \\
\text { (yr of isolation) }\end{array}$ \\
\hline $\begin{array}{l}\text { [Pseudomonas] rubrisub- } \\
\text { albicans }\end{array}$ & $\begin{array}{l}\text { Herbaspirillum rubrisub- } \\
\text { albicans }\end{array}$ & NCPPB $1027^{\mathrm{T}}$ & $\begin{array}{l}\text { LMG } 2286^{\mathrm{T}}, \text { CCUG } \\
17697^{\mathrm{T}}\end{array}$ & NCPPB & $\begin{array}{l}\text { Saccharum officinarum, United States } \\
\text { (1961) }\end{array}$ \\
\hline $\begin{array}{l}\text { [Pseudomonas }] \text { rubrisub- } \\
\text { albicans }\end{array}$ & $\begin{array}{l}\text { Herbaspirillum rubrisub- } \\
\text { albicans }\end{array}$ & NCPPB 519 & $\begin{array}{l}\text { LMG } 1278, \text { CCUG } \\
\quad 17676\end{array}$ & NCPPB & Saccharum officinarum, Mauritius (1956) \\
\hline $\begin{array}{l}{[\text { Pseudomonas }] \text { nibrisub- }} \\
\quad \text { albicans }\end{array}$ & $\begin{array}{l}\text { Herbaspirillum rubrisub- } \\
\text { albicans }\end{array}$ & ICMP 792 & $\begin{array}{l}\text { LMG 6415, CCUG } \\
\qquad 17680\end{array}$ & ICMP & Saccharum officinarum, Reunion (1960) \\
\hline $\begin{array}{l}\text { [Pseudomonas] rubrisub- } \\
\text { albicans }\end{array}$ & $\begin{array}{l}\text { Herbaspinillum rubrisub- } \\
\text { albicans }\end{array}$ & ICMP 3108 & $\begin{array}{l}\text { LMG } 6417, \text { CCUG } \\
17682\end{array}$ & ICMP & Saccharum officinarum, Mauritius (1956) \\
\hline $\begin{array}{l}\text { [Pseudomonas }] \text { rubrisub- } \\
\text { albicans }\end{array}$ & $\begin{array}{l}\text { Herbaspirillum rubrisub- } \\
\text { albicans }\end{array}$ & ICMP 3109 & $\begin{array}{l}\text { LMG 6418, CCUG } \\
\qquad 17683\end{array}$ & ICMP & Saccharum officinarum, Sri Lanka (1956) \\
\hline $\begin{array}{l}{\left[P_{\text {seudomonas }] \text { nibrisub- }}\right.} \\
\quad \text { albicans }\end{array}$ & $\begin{array}{l}\text { Herbaspirillum nubrisub- } \\
\text { albicans }\end{array}$ & ICMP 3110 & $\begin{array}{l}\text { LMG 6419, CCUG } \\
17684\end{array}$ & ICMP & Saccharum officinarum, Tanzania (1964) \\
\hline $\begin{array}{l}{[\text { Pseudomonas }] \text { rubrisub- }} \\
\text { albicans }\end{array}$ & $\begin{array}{l}\text { Herbaspirillum nubrisub- } \\
\text { albicans }\end{array}$ & ICMP 5714 & $\begin{array}{l}\text { LMG 6420, CCUG } \\
\quad 17685\end{array}$ & ICMP & Saccharum officinarum, Jamaica (1961) \\
\hline $\begin{array}{l}\text { [Pseudomonas }] \text { rubrisub- } \\
\text { albicans }\end{array}$ & $\begin{array}{l}\text { Herbaspirillum rubrisub- } \\
\text { albicans }\end{array}$ & IBSBF 198 & LMG 10463 & J. Döbereiner & Saccharum officinarum, Mauritius \\
\hline $\begin{array}{l}{[\text { Pseudomonas }] \text { rubrisub- }} \\
\quad \text { albicans }\end{array}$ & $\begin{array}{l}\text { Herbaspirillum rubrisub- } \\
\text { albicans }\end{array}$ & IBSBF 175 & & J. Döbereiner & Saccharum officinarum, Mauritius \\
\hline Herbaspirillum seropedicae & $\begin{array}{l}\text { Herbaspirillum rubrisub- } \\
\text { albicans }\end{array}$ & HRC 51 & & J. Döbereiner & Sugarcane, roots, Brazil (1992) \\
\hline Herbaspirillum seropedicae & $\begin{array}{l}\text { Herbaspirillum rubrisub- } \\
\text { albicans }\end{array}$ & HCC 103 & & J. Döbereiner & Sugarcane, stems, Brazil (1992) \\
\hline Herbaspirillum seropedicae & $\begin{array}{l}\text { Herbaspinillum rubrisub- } \\
\text { albicans }\end{array}$ & B 4362 & LMG 11128 & J. Döbereiner & Saccharum hybrid, leaves, Brazil (1992) \\
\hline Herbaspinillum seropedicae & $\begin{array}{l}\text { Herbaspirillum rubrisub- } \\
\text { albicans }\end{array}$ & HPD 1 & & J. Döbereiner & Weed plant, roots, Brazil (1992) \\
\hline $\begin{array}{l}\text { [Pseudomonas rubrisub- } \\
\quad \text { albicans] }\end{array}$ & Herbaspirillum seropedicae & Hayward 0312B & $\begin{array}{l}\text { LMG 2284, CCUG } \\
\qquad 17677\end{array}$ & A. Hayward & Saccharum officinarum, Australia (1967) \\
\hline Herbaspirillum seropedicae & Herbaspirillum seropedicae & Z176 & LMG 6512 & J. Döbereiner & Zea mays, roots, Brazil (1982) \\
\hline Herbaspirillum seropedicae & Herbaspirillum seropedicae & $\mathrm{Z} 176^{c}$ & LMG 10656 & J. Döbereiner & Zea mays, roots, Brazil (1982) \\
\hline Herbaspirillum seropedicae & Herbaspirillum seropedicae & $\mathrm{Z} 67^{\mathrm{T}}$ & $\begin{array}{l}\text { LMG } 6513^{\mathrm{T}} \text {, ATCC } \\
\quad 35892\end{array}$ & J. Döbereiner & Oryza sativa, roots, Brazil (1982) \\
\hline Herbaspirillum seropedicae & Herbaspirillum seropedicae & $\mathrm{Z} 67^{\mathrm{T} c}$ & LMG $10657^{\mathrm{T}}$ & J. Döbereiner & Oryza sativa, roots, Brazil (1982) \\
\hline Herbaspirillum seropedicae & Herbaspirillum seropedicae & $\mathrm{Z78}$ & $\begin{array}{l}\text { LMG 6514, ATCC } \\
\quad 35893\end{array}$ & J. Döbereiner & Sorghum bicolor, roots, Brazil (1982) \\
\hline Herbaspirillum seropedicae & Herbaspirillum seropedicae & ${\mathrm{Z} 78^{d}}$ & LMG 10658 & J. Döbereiner & Sorghum bicolor, roots, Brazil (1982) \\
\hline Herbaspirillum seropedicae & Herbaspirillum seropedicae & ZS 12 & LMG 10659 & J. Döbereiner & Sorghum bicolor, roots, Brazil (1986) \\
\hline Herbaspirillum seropedicae & Herbaspirillum seropedicae & Z152 & LMG 10660 & J. Döbereiner & Zea mays, roots, Brazil (1986) \\
\hline Herbaspirillum seropedicae & Herbaspirillum seropedicae & ZAS 74 & & J. Döbereiner & Oryza sativa, roots, Brazil (1986) \\
\hline Herbaspirillum seropedicae & Herbaspirillum seropedicae & HRC 50 & LMG 14778 & J. Döbereiner & Sugarcane, roots, Brazil (1992) \\
\hline Herbaspirillum seropedicae & Herbaspirillum seropedicae & HRC 54 & & J. Döbereiner & Sugarcane, roots, Brazil (1992) \\
\hline Herbaspirillum seropedicae & Herbaspirillum seropedicae & HCC 100 & LMG 14780 & J. Döbereiner & Sugarcane, stems, Brazil (1992) \\
\hline Herbaspirillum seropedicae & Herbaspirillum seropedicae & HCC 102 & LMG 14781 & J. Döbereiner & Sugarcane, stems, Brazil (1992) \\
\hline Herbaspirillum seropedicae & Herbaspirillum seropedicae & HPD 5 & LMG 14784 & J. Döbereiner & Weed plant, roots, Brazil (1992) \\
\hline Herbaspirillum seropedicae & Herbaspinillum seropedicae & HRL brach. & & J. Döbereiner & Brachiaria decumbens, roots, Brazil (1992) \\
\hline Herbaspirillum seropedicae & Herbaspirillum seropedicae & HRL digt. & & J. Döbereiner & Digitaria decumbens, roots, Brazil (1992) \\
\hline Herbaspirillum seropedicae & Herbaspirillum seropedicae & HRL gord. & & J. Döbereiner & Melinis minutiflora, roots, Brazil (1992) \\
\hline Herbaspirillum seropedicae & Herbaspirillum seropedicae & HCC 105 & & J. Döbereiner & Sugarcane, stems, Brazil (1992) \\
\hline $\begin{array}{l}\text { [Pseudomonas rubrisub- } \\
\quad \text { albicans] }\end{array}$ & Herbaspirillum species 3 & NCPPB 932 & $\begin{array}{l}\text { LMG 2285, CCUG } \\
\quad 17678\end{array}$ & NCPPB & Saccharum officinarum, Australia (1961) \\
\hline $\begin{array}{l}\text { [Pseudomonas nubrisub- } \\
\text { albicans] }\end{array}$ & Herbaspirillum species 3 & ICMP 6268 & $\begin{array}{l}\text { LMG } 6421, \text { CCUG } \\
17686 \text { NZRCC } \\
10036\end{array}$ & ICMP & Sorghum sp., New Zealand (1971) \\
\hline $\begin{array}{l}\text { [Pseudomonas rubrisub- } \\
\text { albicans }]\end{array}$ & Herbaspirillum species 3 & ICMP 2850 & $\begin{array}{l}\text { LMG 6416, CCUG } \\
17681\end{array}$ & ICMP & Zea mays cv. rugosa, United States (1961) \\
\hline Unclassified EF group 1 & Herbaspirillum species 3 & CCUG 11060 & LMG 5321 & PHLS & Leg wound, Uddevalla, Sweden (1981) \\
\hline Unclassified EF group 1 & Herbaspirillum species 3 & CCUG 189 & LMG 5523 & PHLS & Contaminant, Göteborg, Sweden (1968) \\
\hline Unclassified EF group 1 & Herbaspirillum species 3 & CCUG 3105 & LMG 6019 & U. Berger & Pharynx, Heidelberg, Germany \\
\hline Unclassified EF group 1 & Herbaspirillum species 3 & CCUG 4446 & LMG 6030 & PHLS & Probably feces, Göteborg, Sweden (1975) \\
\hline Unclassified EF group 1 & Herbaspirillum species 3 & CCUG 6888 & LMG 6020 & PHLS & Wound, Göteborg, Sweden (1980) \\
\hline Unclassified $\mathrm{EF}$ group 1 & Herbaspirillum species 3 & CCUG 6997 & LMG 6021 & H. Lomberg & Urine, Göteborg, Sweden (1978) \\
\hline Unclassified EF group 1 & Herbaspirillum species 3 & CCUG 8038 & LMG 6022 & PHLS & Otitis, Göteborg, Sweden (1979) \\
\hline Unclassified EF group 1 & Herbaspirillum species 3 & CCUG 10143 & LMG 6023 & G. Lidin-Jansson & Tibia fracture, Göteborg, Sweden (1980) \\
\hline Unclassified EF group 1 & Herbaspirillum species 3 & CCUG 10221 & LMG 5522 & PHLS & Gastric juice, Göteborg, Sweden (1980) \\
\hline Unclassified EF group 1 & Herbaspirillum species 3 & CCUG 10263 & LMG 5934 & PHLS & Eye, Uddevalla, Sweden (1980) \\
\hline Unclassified EF group 1 & Herbaspirillum species 3 & CCUG 12558 & LMG 6026 & PHLS & Wound, Göteborg, Sweden (1980) \\
\hline Unclassified EF group 1 & Herbaspirillum species 3 & CCUG 12633 & LMG 6027 & PHLS & Respiratory tract, Göteborg, Sweden (1980) \\
\hline
\end{tabular}


TABLE $1-$ Continued

\begin{tabular}{|c|c|c|c|c|c|}
\hline Name as received & Taxonomic position $^{a}$ & Strain no. ${ }^{b}$ & $\begin{array}{l}\text { Other strain } \\
\text { designation }^{b}\end{array}$ & $\begin{array}{l}\text { Received } \\
\text { from }^{b}\end{array}$ & $\begin{array}{c}\text { Source } \\
\text { (yr of isolation) }\end{array}$ \\
\hline Unclassified EF group 1 & Herbaspirillum species 3 & CCUG 12962 & LMG 6024 & PHLS & $\begin{array}{l}\text { Septic arthritis of knee joint } \\
\text { Göteborg, Sweden (1982) }\end{array}$ \\
\hline Unclassified EF group 1 & Herbaspirillum species 3 & CCUG 13048 & LMG 6025 & PHLS & $\begin{array}{l}\text { Axillar aspiration, Göteborg, Sweden } \\
\text { (1982) }\end{array}$ \\
\hline Unclassified EF group 1 & Herbaspirillum species 3 & CCUG 13403 & LMG 6028 & PHLS & Ear, Göteborg, Sweden (1983) \\
\hline Unclassified EF group 1 & Herbaspirillum species 3 & CCUG 14952 & LMG 6029 & PHLS & Leg wound, Göteborg, Sweden (1984) \\
\hline Unclassified EF group 1 & Herbaspirillum species 3 & CCUG 15235 & $\begin{array}{l}\text { LMG 5935, CDC } \\
\text { F2754 }\end{array}$ & D. Hollis, CDC & Bacteremia, Honolulu, Hawaii (1982) \\
\hline Unclassified EF group 1 & Herbaspirillum species 3 & CCUG 17849 & LMG 6799 & G. Gilardi & United States (1985) \\
\hline Unclassified EF group 1 & Herbaspirillum species 3 & CCUG 20016 & LMG 7680 & PHLS & Eye secretion, Göteborg, Sweden (1987) \\
\hline Ianthinobacterium lividum & Janthinobacterium lividum & CCUG 15937 & $\begin{array}{l}\text { LMG 6356, CCM } \\
\quad 3355\end{array}$ & $\mathrm{CCM}$ & Effluent of abattoir \\
\hline Ianthinobacterium lividum & Janthinobacterium lividum & NCTC $9796^{\mathrm{T}}$ & $\begin{array}{l}\text { LMG } 2892^{\mathrm{T}} \\
(=\text { Sneath HB), } \\
\text { CCUG } 2344^{\mathrm{T}}\end{array}$ & NCTC & Soil, Michigan (1952) \\
\hline Ianthinobacterium lividum & Janthinobacterium lividum & CCUG 3359 & $\begin{array}{l}\text { LMG 6035, NCIB } \\
\quad 7917\end{array}$ & NCIB & Lake water, United Kingdom \\
\hline Janthinobacterium lividum & Janthinobacterium lividum & NCTC 7150 & $\begin{array}{l}\text { LMG 3923, CCUG } \\
\qquad 15726\end{array}$ & NCTC & Water \\
\hline Janthinobacterium lividum & Janthinobacterium lividum & Sneath RU & $\begin{array}{l}\text { LMG 3934, CCUG } \\
15727, \text { NCIP } 9230\end{array}$ & P.H.A. Sneath & Soil, United Kingdom \\
\hline Janthinobacterium lividum & Janthinobacterium lividum & Sneath HA & $\begin{array}{l}\text { LMG 3931, CCUG } \\
15728, \text { NCIB } 9217\end{array}$ & P.H.A. Sneath & Soil, Michigan \\
\hline Janthinobacterium lividum & Janthinobacterium lividum & Sneath MB & $\begin{array}{l}\text { LMG 3919, CCUG } \\
\quad 15729\end{array}$ & P.H.A. Sneath & Water of sand filter, United Kingdom \\
\hline Janthinobacterium lividum & Janthinobacterium lividum & ATCC 14487 & $\begin{array}{l}\text { LMG 3927, CCUG } \\
\quad 15730\end{array}$ & ATCC & Pasteurized commercial cream \\
\hline Burkholderia cepacia ${ }^{d}$ & & ATCC 25609t1 & LMG 6981 & & \\
\hline Ralstonia pickettiid & & CCUG $3318^{\mathrm{T}}$ & LMG $5942^{\mathrm{T}}$ & & \\
\hline Iodobacter fluviatile ${ }^{d}$ & & USCC 2237 & LMG 6573 & & \\
\hline Oligella ureolytica $^{d}$ & & CCUG $1465 A^{T}$ & LMG $6519^{\mathrm{T}}$ & & \\
\hline Comamonas terrigena $a^{d}$ & & NCIB 2581 & LMG 1249 & & \\
\hline $\begin{array}{l}\text { Acidovorax avenae subsp. } \\
\text { avenae }^{d}\end{array}$ & & NCPPB $1011^{\mathrm{T}}$ & LMG $2117^{\mathrm{T}}$ & & \\
\hline
\end{tabular}

${ }^{a}$ As proposed in this study.

${ }^{b}$ Abbreviations: ATCC, American Type Culture Collection, Rockville, Md; CCM, Czechoslovak Collection of Microorganisms, Brno, Czech Republic; CCUG, Culture Collection University of Göteborg, Department of Clinical Bacteriology, Göteborg Sweden; DSM, Deutsche Sammlung von Mikroorganismen und Zellkulturen, GmbH, Braunschweig, Germany; ICMP, International Collection of Micro-organisms from Plants, Plant Diseases Division, DSIR Mount Albert Research Centre, Auckland, New Zealand; LMG, Culture Collection, Laboratory of Microbiology, Universiteit Gent, Ghent, Belgium; NCPPB, National Collection of Plant Pathogenic Bacteria, Harpenden Laboratory, Hertsfordshire, United Kingdom; NCIB, National Collection of Industrial Bacteria, Aberdeen, Scotland; NCTC, National Collection of Type Cultures, Central Public Health Laboratory, London, United Kingdom; NZRCC, New Zealand Reference Culture Collection (Plant and Soil), DSIR Plant Diseases, Auckland, New Zealand; PHLS, Public Health Laboratory, Sweden; USCC, University of Surrey Culture Collection, Department of Microbiology, University of Surrey, Guilford, Surrey, United Kingdom; brach., Bracharia; digt., Digitaria; gord., from "capim gordura" (Melinis minuitiflora).

${ }^{c}$ For some cultures, we separately investigated two subcultures obtained on different dates.

${ }^{d}$ Representative strains from other rRNA branches of the $\beta$-subclass of the Proteobacteria.

rubrisubalbicans LMG $2286^{\mathrm{T}}$ was prepared and purified by the method described by De Ley and De Smedt (8). Cells were labeled in vivo by addition of $1.8 \mathrm{mCi}$ of $\left[5,6{ }^{3} \mathrm{H}\right]$ uracil (New England Nuclear Research Products, Boston, Mass.) to $100 \mathrm{ml}$ (wt/vol) of the following medium: peptone, $1 \%$; succinate, $0.1 \% ;\left(\mathrm{NH}_{4}\right)_{2} \mathrm{SO}_{4}$ $0.1 \% ; \mathrm{MgSO}_{4} \cdot 7 \mathrm{H}_{2} \mathrm{O}, 0.1 \% ; \mathrm{FeCl}_{3} \cdot 6 \mathrm{H}_{2} \mathrm{O}, 0.0002 \% ; \mathrm{MnSO}_{4} \cdot 6 \mathrm{H}_{2} \mathrm{O}, 0.0002 \%$ $(\mathrm{pH} 7)$ with $\mathrm{KOH}$. The activity of the $23 \mathrm{~S}$ fraction was $30,000 \mathrm{dpm}$.

DNA-DNA hybridizations. The initial renaturation method was used (7); the optimal renaturation conditions were $2 \times \operatorname{SSC}(1 \times$ SSC is $0.15 \mathrm{M} \mathrm{NaCl}$ plus 0.015 $\mathrm{M}$ Na citrate $[\mathrm{pH} 7.0])$ and $T_{\mathrm{OR}(2)}\left[T_{\mathrm{OR}(2)}\right.$ is optimal renaturation temperature in $2 \times \mathrm{SSC}$ ] of $71^{\circ} \mathrm{C}$

Species-specific probes. Oligonucleotide probes complementary to a highly variable stretch of helix 55 to 59 (numbering according to reference 19) of the 23S rRNA of $H$. seropedicae (sequenced strain was ATCC $35892^{\mathrm{T}}$ ) and $H$. rubrisubalbicans (sequenced strain was LMG $2286^{\mathrm{T}}$ ) were designed. Probes with 19 base lengths were synthesized (probe HS, $5^{\prime}$-GTC CCG GTT TTT GCA TCG A-3'; probe HR, 5'-TAG TCG GTT TTT GCA TCG A-3'), and species specificity was confirmed by hybridization experiments with the rRNA of 80 different soil- and plant-associated bacteria (data not shown). The bulk nucleic acid of all strains was isolated according to a method described by Oelmuller et al. (25) and transferred to a nylon membrane (Quiagen-plus; Diagen) via spot blotting. The hybridization with radioactive labeled probes was performed for 2 to $12 \mathrm{~h} \mathrm{at} 52^{\circ} \mathrm{C}$ according to the method of Kirchhof and Hartmann (21). Signals were detected by autoradiography.

Phenotypic tests. API galleries (API 50CH, API 50AO, and API 50AA; bio-
Mérieux, Montalieu-Vercieu, France) were used to test the assimilation of 147 organic compounds as sole carbon sources. The experimental procedure we used has been described previously (20). All strains were tested; several of the strains were included in duplicate on separate occasions to verify the reproducibility of the tests. The results of auxanographic tests were scored as described previously (20). Of the 147 features tested, 44 tests (given in a footnote to Table 2) were not included in the numerical analysis because they gave a negative result. The levels of interstrain similarity $(S)$ were calculated with a similarity coefficient derived from the Canberra metric coefficient $\left(d_{\mathrm{CANB}}\right)$ (33) and the following equation: $S=100 \times\left(1-d_{\mathrm{CANB}}\right)$. A cluster analysis was performed with the unweighted average pair group method (33), the Clustan 2.1 program of Wishart (38), and the Siemens model 7570-C computer of the Centraal Digitaal Rekencentrum, Universiteit, Ghent, Belgium.

The ability to catabolize some of these carbon sources was also evaluated with semisolid JNFb medium, in which malate was replaced by the carbon substrates. Growth dependent on nitrogen fixation or $\mathrm{NH}_{4}^{+}$was evaluated by pellicle formation.

\section{RESULTS AND DISCUSSION}

Polyphasic taxonomy in the genus Herbaspirillum. The fine phenotypic relationships between a number of representative strains of $H$. seropedicae, $[P$.] rubrisubalbicans, EF group 1, and 
TABLE 2. Auxanographic results

\begin{tabular}{|c|c|c|c|c|c|}
\hline \multirow{3}{*}{ Substrate } & \multicolumn{5}{|c|}{ Auxanographic result for organism by phenon ${ }^{a}$} \\
\hline & \multicolumn{2}{|c|}{ Herbaspirillum species 3} & \multirow{2}{*}{$\begin{array}{l}\text { H. rubrisubalbicans } \\
\text { (phenon II } \\
[n=8])\end{array}$} & \multirow{2}{*}{$\begin{array}{l}\text { H. seropedicae } \\
\text { (phenon III } \\
\quad[n=7])\end{array}$} & \multirow{2}{*}{$\begin{array}{l}\text { J. lividum } \\
\text { (phenon IV } \\
{[n=8] \text { ) }}\end{array}$} \\
\hline & $\begin{array}{l}\text { Phenon Ia } \\
(n=8)\end{array}$ & $\begin{array}{l}\text { Phenon Ib } \\
(n=14)\end{array}$ & & & \\
\hline $\begin{array}{l}\text { Arbutin, salicin, D-cellobiose, maltose sucrose, trehalose, inulin, } \\
\text { D-tartrate, D-raffinose, starch, L-phenylalanine, DL-5-aminovaler- } \\
\text { ate, betaine, glutarate, L-histidine }\end{array}$ & - & - & - & - & $\mathrm{d}$ \\
\hline $\begin{array}{l}\text { Adonitol, D-galactose, L-fucose, L-arabitol, gluconate, } 2 \text {-ketogluco- } \\
\text { nate, propionate, isobutyrate, } n \text {-valerate, isovalerate, D-malate, } \\
\text { meso-tartrate, butyrate, DL-4-aminobutyrate, aconitate, } p \text {-hydroxy- } \\
\text { benzoate, L-proline, D-arabinose }\end{array}$ & + & + & + & + & d \\
\hline Ethanolamine & + & + & $\mathrm{d}$ & + & - \\
\hline $\begin{array}{l}\text { 5-Ketogluconate, acetate, caprate, amylamine, D-fucose, } \\
\text { tryptamine }\end{array}$ & + & + & + & + & - \\
\hline meso-Erythritol ${ }^{b}$ & + & - & + & - & - \\
\hline L-Rhamnose ${ }^{b}$ & - & - & - & + & $\mathrm{d}$ \\
\hline meso-Inositol ${ }^{b}$ & - & - & - & + & + \\
\hline$N$-Acetylglucosamine ${ }^{b}$ & + & + & - & + & $\mathrm{d}$ \\
\hline Suberate $^{b}$ & + & + & - & - & + \\
\hline L-Tartrate ${ }^{b}$ & + & + & - & - & - \\
\hline Sebacate $^{b}$ & + & $\mathrm{d}$ & - & - & + \\
\hline Adipate, pimelate, azelate ${ }^{b}$ & + & + & - & - & d \\
\hline Benzoate $^{b}$ & + & - & + & $\mathrm{d}$ & - \\
\hline Lactose, glucosamine & $\mathrm{d}$ & d & - & - & $\mathrm{d}$ \\
\hline Malonate & $\mathrm{d}$ & $\mathrm{d}$ & - & - & - \\
\hline L-Xylose, caprylate & $\mathrm{d}$ & $\mathrm{d}$ & d & d & - \\
\hline Glycolate & + & d & - & - & - \\
\hline Phenylacetate, L-tyrosine, $n$-valerate, L-tryptophan & + & $\mathrm{d}$ & + & + & $\mathrm{d}$ \\
\hline$o$-Hydroxybenzoate & $\mathrm{d}$ & - & - & - & - \\
\hline D-Mandelate & - & - & $\mathrm{d}$ & - & - \\
\hline L-Mandelate, itaconate, mesaconate & $\mathrm{d}$ & + & + & + & - \\
\hline D- $\alpha$-Alanine & + & d & d & + & + \\
\hline $\mathrm{L}-\alpha$-Alanine, L-isoleucine & + & $\mathrm{d}$ & + & + & + \\
\hline L-Norleucine & $\mathrm{d}$ & $\mathrm{d}$ & $\mathrm{d}$ & $\mathrm{d}$ & $\mathrm{d}$ \\
\hline L-Valine & $\mathrm{d}$ & d & d & d & + \\
\hline Heptanoate & $\mathrm{d}$ & - & $\mathrm{d}$ & d & - \\
\hline L-Serine, pelargonate & + & $\mathrm{d}$ & + & d & + \\
\hline L-Cysteine & d & $\mathrm{d}$ & + & d & d \\
\hline$\beta$-Alanine & d & $\mathrm{d}$ & + & + & - \\
\hline Butylamine & d & + & $\mathrm{d}$ & + & - \\
\hline DL-3-Aminobutyrate & $\mathrm{d}$ & - & + & $\mathrm{d}$ & - \\
\hline Benzylamine & - & - & - & d & - \\
\hline
\end{tabular}

${ }^{a}+$, present in $90 \%$ or more of the strains; - , present in $10 \%$ or less of the strains; $\mathrm{d}, 11$ to $89 \%$ of all strains positive. All strains were negative for methyl-xyloside, L-sorbose, dulcitol, methyl-D-mannoside, methyl-D-glucoside, amygdalin, esculin, D-melibiose, D-melezitose, glycogen, $\beta$-gentiobiose, D-turanose, D-tagatose, citraconate, levulinate, $m$-hydroxybenzoate, phthalate, isophthalate, terephthalate, $n$-capronate, oxalate, maleate, glycine, DL-norvaline, DL-2-aminobutyrate, L-methionine, D-tryptophan, trigonelline, L-ornithine, L-lysine, L-citrulline, L-arginine, DL-kynurenine, creatine, 2-aminobenzoate, 3-aminobenzoate, 4-aminobenzoate, ureum, acetamide, sarcosine, ethylamine, diaminobutane, spermine, and histamine. All strains were positive for glycerol, L-arabinose, ribose, D-xylose, D-glucose, D-fructose, D-mannose, mannitol, sorbitol, xylitol, D-lyxose, D-arabitol, DL-lactate, DL-glycerate, DL-3-hydroxybutyrate, L-malate, pyruvate, citrate, succinate, fumarate, L-leucine, L-threonine, L-aspartate, L-glutamate, and 2-ketoglutarate.

${ }^{b}$ Differentiating substrates.

J. lividum were studied by an auxanographic analysis of 147 substrates. The results are given in Fig. 1. Four phena were delineated. J. lividum strains (phenon IV) constitute a separate cluster that is the most divergent from the other three clusters (phena I to III). Phenon I contains all EF group 1 strains and three $[P$.] rubrisubalbicans strains, LMG 2285, LMG 6421, and LMG 6416. Within this phenon, two subgroups, a and b, could be differentiated above $85 \% \mathrm{~S}$, with subgroup a containing the three $[P$.] rubrisubalbicans strains. Phenon II contains only $[P$.] rubrisubalbicans strains, including the type strain, and phenon III consists of nine $H$. seropedicae strains and one $[P$.] rubrisubalbicans strain (LMG 2284). The reproducibility of the results varied from 95 to $97 \%$. The auxanographic features of these four phena are given in Table 2; for clarity, the subgroups of phenon I were kept separate. Representative strains of the four phena were used for DNA-rRNA hybridizations in order to study the inter- and intrageneric similarities between the four phena. The $T_{m(e)}$ values (temperature in degrees Celsius at which $50 \%$ of the hybrid is denatured under standard conditions [8]) of the DNA-rRNA hybrids with rRNA from $[P$.] rubrisubalbicans LMG $2286^{\mathrm{T}}$ are given in Table 3. [P.] rubrisubalbicans, $H$. seropedicae, the EF group 1 organisms, and $J$. lividum constitute a separate rRNA cluster and are closely related $\left[T_{m(e)}\right.$ of 76.2 to $\left.79.7^{\circ} \mathrm{C}\right]$. Within rRNA superfamily III ( $\beta$-subclass of the Proteobacteria [34]), this cluster constitutes a separate rRNA branch with Burkholderia and the other members of the former solanacearum rRNA complex as its closest neighbors $\left(T_{m(e)}\right.$ of 73.9 to $\left.74.4^{\circ} \mathrm{C}\right)(17)$. The position of the separate rRNA cluster is given in a $T_{m(e)}$ dendrogram in Fig. 2. It has been shown before that members of an rRNA cluster 


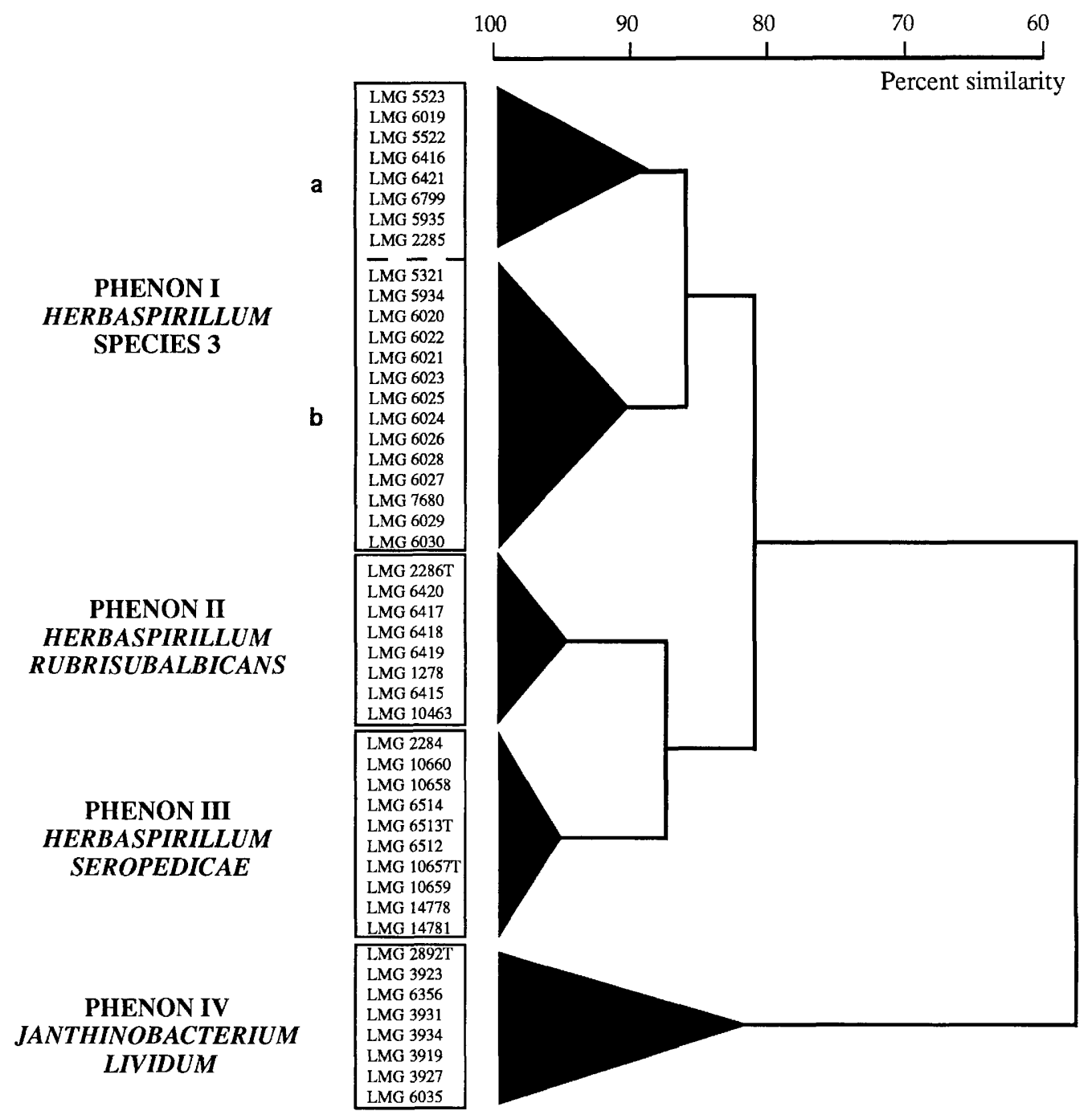

FIG. 1. Dendrogram derived from an unweighted average pair group cluster analysis of similarity coefficients obtained by comparison of the results of 103 auxanographic tests for strains belonging to the Herbaspirillum rRNA branch.

with differences ( 3 to $4^{\circ} \mathrm{C}$ ) in their $T_{m(e)}$, comparable to what we will call the Herbaspirillum rRNA cluster, can be considered as belonging to a single genus (6). Because J. lividum has the lowest $T_{m(e)}$ value within this rRNA cluster and is phenotypically quite distinct from the other members of this rRNA branch $(15,30,32)$, we propose to keep this genus separate and to unify the other members of this rRNA cluster into a single genus. According to the nomenclatural rules (22), the name Herbaspirillum has priority because its type species belongs to this rRNA cluster and because the other members of this genus carry no official name or have generically been misnamed according to the present phylogenetic data.

In order to examine the intrageneric relationships within Herbaspirillum, we used DNA-DNA hybridizations between members of the different phena (I to III); a representative $J$. lividum strain was included as a control. The results of DNADNA hybridizations are given in Fig. 3 and revealed three homology groups (I to III) corresponding to the respective Herbaspirillum phena. Within groups II and III, very high values of DNA-DNA hybridization were found (71 to $100 \%$ ). However, within group I, the percentage of binding varied between 52 and $100 \%$, and two subgroups of phenon I can be differentiated, namely subgroup Ib (89 to $100 \%$ ) and subgroup Ia (86 to $100 \%$ ), with $56 \%$ DNA binding between both subgroups. Low $(\leq 40 \%)$ or nonsignificant values ( $<30 \%$ binding) were found between the different Herbaspirillum groups and with a representative $J$. lividum strain. It is clear that the three Herbaspirillum DNA groups represent at least three genomic species that do correspond to the three phena found, within the genus Herbaspirillum. Although it is recommended that species should share at least $70 \%$ DNA homology, together with a maximum $5^{\circ} \mathrm{C} \Delta T_{m}$ when the $\mathrm{S} 1$ nuclease hybridization method is used (37), it is our experience that this species delineation threshold for the initial renaturation method corresponds to percentages of DNA binding above $40 \%$. As a consequence, we conclude that there are at least three species within the genus Herbaspirillum. (i) $H$. seropedicae corresponds to phenon III and contains the $H$. seropedicae strains, including the type strain. Strain LMG 2284, which was classified before with the name $[P$.] rubrisubalbicans, is, on the basis of phenotypic and genotypic data, certainly a member of $H$. seropedicae. (ii) Also within the genus Herbaspirillum are the [P.] rubrisubalbicans strains of phenon II, including the type strain, which as a consequence should be named $H$. rubrisubalbicans. (iii) Fi- 
TABLE 3. $T_{m(e)}$ of DNA-rRNA hybrids with labeled rRNA from $H$. rubrisubalbicans LMG $2286^{\mathrm{T}}$ and J. lividum LMG $2892^{\mathrm{T}}$

\begin{tabular}{|c|c|c|c|}
\hline \multirow{2}{*}{ DNA } & \multirow{2}{*}{$\begin{array}{c}\% \\
\mathrm{G}+\mathrm{C} \\
\text { content }\end{array}$} & \multicolumn{2}{|c|}{$\begin{array}{c}T_{m(e)}\left({ }^{\circ} \mathrm{C}\right) \text { of DNA-rRNA } \\
\text { hybrid with } 23 \mathrm{~S} \\
\text { rRNA from: }\end{array}$} \\
\hline & & $\begin{array}{l}\text { H. rubrisub- } \\
\text { albicans } \\
\text { LMG } 2286^{\mathrm{T}}\end{array}$ & 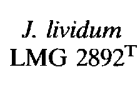 \\
\hline $\begin{array}{l}\text { Herbaspirillum rubrisubalbicans } \\
\text { LMG } 2286^{\text {T }}\end{array}$ & 62.5 & 79.7 & \\
\hline Herbaspirillum seropedicae LMG 6512 & & 77.4 & \\
\hline Herbaspirillum seropedicae LMG $6513^{\mathrm{T}}$ & 64.5 & 78.3 & \\
\hline Herbaspirillum seropedicae LMG 6514 & 65 & 77.1 & \\
\hline Herbaspirillum seropedicae LMG 10659 & & 77.8 & \\
\hline Herbaspirillum seropedicae LMG 2284 & & 77.5 & \\
\hline Herbaspirillum seropedicae LMG 11128 & & 78.3 & \\
\hline Herbaspirillum species 3 LMG 5523 & 61 & 79.3 & 75.8 \\
\hline Herbaspirillum species 3 LMG 5321 & & 79.1 & 76.1 \\
\hline Herbaspirillum species 3 LMG 2285 & & 77.0 & \\
\hline Janthinobacterium lividum LMG $2892^{\mathrm{T}}$ & 65.5 & 76.2 & 78.8 \\
\hline Burkholderia cepacia LMG 6981 & 69.0 & 73.9 & \\
\hline Ralstonia pickettii LMG $5942^{\mathrm{T}}$ & & 74.4 & \\
\hline Iodobacter fluviatile LMG 6573 & & 69.3 & \\
\hline Oligella ureolytica LMG $6519^{\mathrm{T}}$ & & 69.5 & \\
\hline Comamonas terrigena LMG 1249 & 66 & 70.0 & \\
\hline $\begin{array}{l}\text { Acidovorax avenae subsp. avenae } \\
\text { LMG } 2117^{\mathrm{T}}\end{array}$ & 62.5 & 71.4 & \\
\hline
\end{tabular}

nally, most EF group 1 strains should be included, together with three strains that have been named $[P$.] rubrisubalbicans and which we refer to as Herbaspirillum species 3 until a full proposition with a proper species description can be given (14).

It is not so obvious that nitrogen-fixing bacteria like $H$. seropedicae can also be plant pathogenic and that they are closely related to bacteria isolated from clinical environments. In fact, only intensive DNA-rRNA hybridizations with a wide variety of proteobacteria allowed us to establish the intrageneric relationship between $H$. seropedicae, $H$. rubrisubalbicans, and Herbaspirillum sp. 3. We do not have a plausible explanation for such relationships that were also found in such other genera as Arcobacter (35) and Burkholderia (17).

All Herbaspirillum species grown in the API 50CH, 50AO, and 50AA systems used the following substrates: glycerol, Dand L-arabinose, ribose, D-xylose, D-glucose, D-fructose, D-mannose, mannitol, sorbitol, xylitol, D-lyxose, DL-lactate, DL-glycerate, DL-3-hydroxybutyrate, pyruvate, citrate, succinate, fumarate, Lleucine, L-threonine, L-aspartate, L-glutamate, 2-ketoglutarate, adonitol, D-galactose, L-fucose, D- and L-arabitol, gluconate, 2 -ketogluconate, propionate, isobutyrate, $n$-valerate, isovalerate, D- and L-malate, meso-tartrate, butyrate, DL-4-aminobutyrate, aconitate, mesaconate, $p$-hydroxybenzoate, L-proline, D-arabinose, 5-ketogluconate, acetate, caprate, amylamine, Dfucose, and tryptamine.

The following auxanographic features were shown to be discriminative between the three species: meso-erythritol, $\mathrm{N}$ acetylglucosamine, L-rhamnose, meso-inositol, azelate, sebacate, pimelate, suberate, adipate, and L-tartrate.

The endophytic occurrence of $H$. seropedicae and $H$. rubrisubalbicans reported earlier $(4,11)$ was recently confirmed (27). Neither of the two diazotrophic species could be isolated from soil samples. The occurrence of these diazotrophic bacteria in plants can be explained by their dissemination via the seeds (1). Among a large number of samples of roots, stems, and leaves from 13 species of the family Gramineae collected at various sites, we could not detect $H$. seropedicae only in the species Paspalum notatum, Digitaria insularis, and Echinocloa crusgalli. On the other hand, $H$. rubrisubalbicans could be isolated only from sugarcane (Saccharum spp.) and from one sample of a weed plant, $D$. insularis, collected in a sugarcane field. In various samples of weeds collected within maize and sugarcane fields (of the families Compositae, Molluginaceae, Sterculiaceae, Cyperaceae, Portulacaceae, Leguminosae, and Cucurbitaceae), we could not detect either Herbaspirillum species. In contrast to $H$. seropedicae, $H$. rubrisubalbicans was not detected in samples of forage grasses grown at different sites of EMBRAPA-CNPAB, Rio de Janeiro, Brazil (27).

Because of the endophytic occurrence of $H$. rubrisubalbicans and $H$. seropedicae $(4,11)$, it was important to focus on some important but simple features that can distinguish both species from each other and from the other Herbaspirillum species. Strains of $H$. seropedicae have one to three flagella at one or both poles, show optimum growth at $34^{\circ} \mathrm{C}$, and use $\mathrm{N}$-acetylglucosamine but not meso-erythritol as a sole carbon source both in API $50 \mathrm{CH}$ and in the classical test procedure. In contrast, strains of $H$. rubrisubalbicans have multiple flagella at one pole, show optimum growth at $30^{\circ} \mathrm{C}$, and do not use $N$ acetylglucosamine but use meso-erythritol as a sole carbon source in API $50 \mathrm{CH}$ and in the classical procedure, when performed in the presence of inorganic nitrogen $\left(\mathrm{NH}_{4} \mathrm{Cl}\right)(\mathrm{Ta}-$ ble 4). In addition, they cause mottled stripe disease on the sensitive sugarcane variety B-4362 (29). Herbaspirillum species 3 strains from subphenon Ia use meso-erythritol in the API $50 \mathrm{CH}$ system, while the members of subphenon $\mathrm{Ib}$ do not. However, in the classical procedure, members of both subphena are positive for meso-erythritol. In contrast to Herbaspirillum species $3, H$. seropedicae and $H$. rubrisubalbicans are able to fix dinitrogen. The only exception was $H$. seropedicae LMG 2284 , which is unable to fix dinitrogen.

The ability of Herbaspirillum species to catabolize $\mathrm{N}$-acetyl-

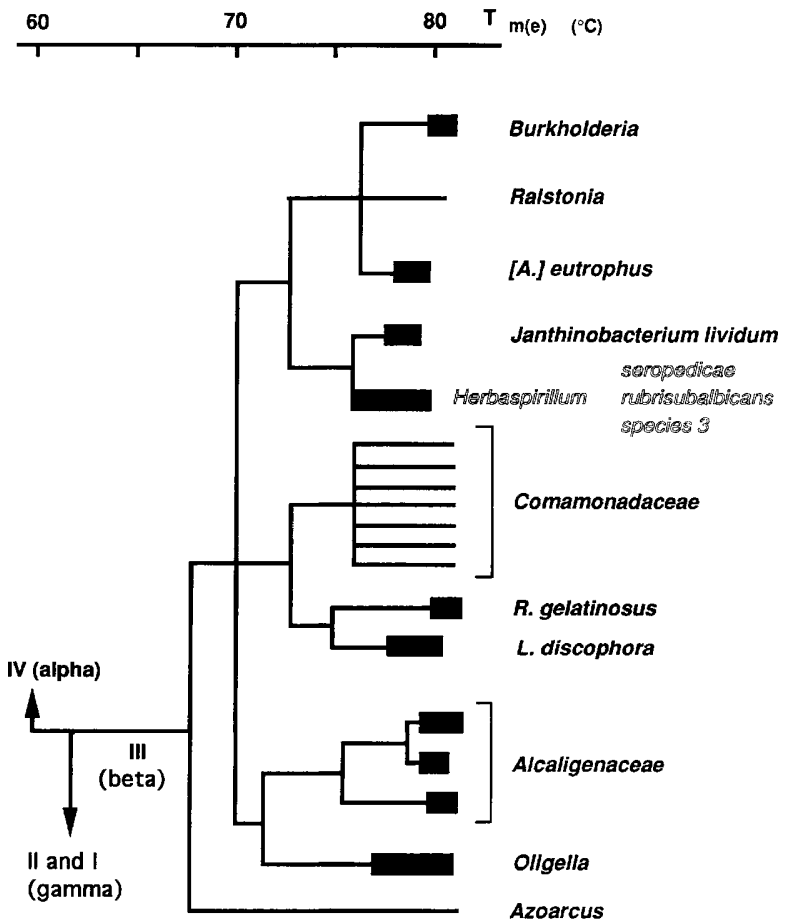

FIG. 2. $T_{m(e)}$ dendrogram showing the position of Herbaspirillum within rRNA superfamily III ( $\beta$-subclass). A., Alcaligenes; L., Leptothrix; R., Rhodocyclus. 


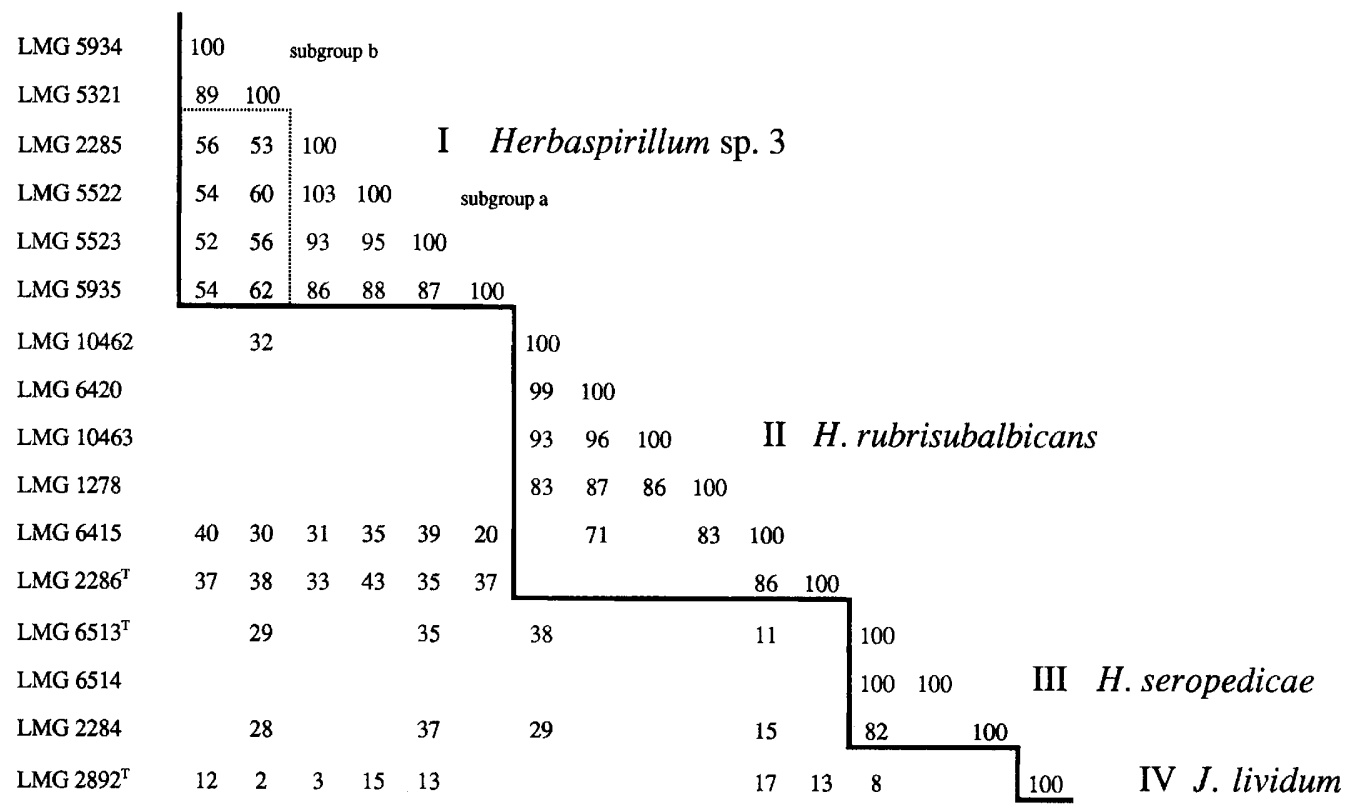

FIG. 3. Results of DNA-DNA hybridization.

glucosamine and/or meso-erythritol was confirmed by classical procedures with a larger group of endophytic strains (Table 4). Eight more strains previously classified as $H$. seropedicae used $\mathrm{N}$-acetylglucosamine but not meso-erythritol ( $\mathrm{N}$-acetylglucosamine group), while another five strains, previously classified as $[P$.] rubrisubalbicans, catabolized meso-erythritol in the presence of $\mathrm{NH}_{4} \mathrm{Cl}$ but not $\mathrm{N}$-acetylglucosamine (meso-erythritol group). Both physiological groups (meso-erythritol and $N$-acetylglucosamine) were also tested with specific oligonucleotide probes based on highly variable stretches of their 23S rRNA. The results are presented in Table 4 . The $H$. seropedicae oligonucleotide probe (HS) could definitely identify all strains of the $N$-acetylglucosamine group as $H$. seropedicae strains. The HR oligonucleotide probe could not distinguish strains of $H$. rubrisubalbicans from strains of Herbaspirillum species 3. In addition, sequence comparison of the hypervariable region (helix positions 55 to 59) of the 23S rRNA from $H$. rubrisubalbicans LMG $2286^{\mathrm{T}}$ and those of strains from Herbaspirillum species 3 (LMG 5934, LMG 5523, and LMG 2285, representing both subgroups) showed no sequence variation (data not shown). The two subgroups of Herbaspirillum species 3 also could not be distinguished, because all members of the third species showed growth on meso-erythritol by conventional tests, while in contrast, in API $50 \mathrm{CH}$, only members of subgroup Ia reacted positively to meso-erythritol (Table 2). However, both species of the meso-erythritol group could be further differentiated by their ability to fix $\mathrm{N}_{2}$ and by their growth on adipate, pimelate, suberate, azelate, sebacate, and L-tartrate (Table 2).

Emended description of Herbaspirillum (Baldani, Baldani, Seldin, and Döbereiner 1986). Herbaspirillum (Her.ba.spi'ril. lum. L. fem. n. herba, herbaceous seed-bearing plant that does not produce persistent woody tissue; M.L. dim. neut. n. spirillum, small spiral; Herbaspirillum, small spiral-shaped bacteria from herbaceous seed-bearing plants).

Cells are gram negative, generally vibroid, and sometimes helical. The cells have one to three or more flagella on one or both poles. The cell diameter is 0.6 to $0.7 \mu \mathrm{m}$, and the cell length varies with the medium from 1.5 to $5.0 \mu \mathrm{m}$. The organ- ism has a typical respiratory metabolism, and sugars are not fermented. Some species fix atmospheric $\mathrm{N}_{2}$ under microaerobic conditions and grow well with $\mathrm{N}_{2}$ as a sole nitrogen source, even in up to $10 \%$ sucrose. The organism is oxidase and urease positive; catalase is weak or variable. Organic acids are the favored carbon sources for growth. All species grow on glycerol, D- and L-arabinose, ribose, D-xylose, D-glucose, D-fructose, D-mannose, mannitol, sorbitol, xylitol, D-lyxose, DL-lactate, DL-glycerate, DL-3-hydroxybutyrate, pyruvate, citrate, succinate, fumarate, L-leucine, L-threonine, L-aspartate, L-glutamate, 2-ketoglutarate, adonitol, D-galactose, L-fucose, D- and L-arabitol, gluconate, 2-ketogluconate, propionate, isobutyrate, $n$-valerate, isovalerate, $\mathrm{D}$ - and L-malate, meso-tartrate, butyrate, DL-4-aminobutyrate, aconitate, mesaconate, p-hydroxybenzoate, L-proline, D-arabinose, 5-ketogluconate, acetate, caprate, amylamine, D-fucose, and tryptamine.

The genus constitutes a separate rRNA cluster within the $\beta$-subclass of the Proteobacteria.

The $\mathrm{G}+\mathrm{C}$ content of the DNA is 60 to $65 \%$ (as determined by thermal denaturation).

The type species is $H$. seropedicae.

Emended description of $\boldsymbol{H}$. seropedicae (Baldani, Baldani, Seldin, and Döbereiner 1986). $H$. seropedicae (se.ro.ped'i.cae L. gen. n. seropedicae, of Seropédica, Rio de Janeiro, Brazil, where the species was first isolated). Cells are vibroid and sometimes helical and become very motile when close to an $\mathrm{O}_{2}$ source. The cells have generally two polar flagella (occasionally one to three flagella) on one or on both poles. On soft nutrient agar at $35^{\circ} \mathrm{C}$, pronounced swarming occurs. Most strains fix atmospheric $\mathrm{N}_{2}$ under microaerobic conditions and grow well with $\mathrm{N}_{2}$ as a sole nitrogen source. The efficiency of $\mathrm{N}_{2}$ fixation in semisolid $\mathrm{NFb}$ medium is 12 to $15 \mathrm{mg}$ of $\mathrm{N}_{2}$ per $\mathrm{g}$ of DL-malate. Growth in the presence of $\mathrm{N}_{2}$ is slower than the growth of Azospirillum spp., but the growth in the presence of mineral nitrogen or glutamate is much faster. The organism does not grow in the presence of $2 \% \mathrm{NaCl}$. Vitamins or growth substances are not required. The organism is susceptible to chloramphenicol, tetracycline, gentamicin, kanamycin, erythromycin, and streptomycin and is resistant to penicillin. The 
TABLE 4. Use of meso-erythritol and $N$-acetylglucosamine (independent of $\mathrm{N}_{2}$ fixation) and hybridization with the oligonucleotide probes HR (H. rubrisubalbicans) and HS (H. seropedicae)

\begin{tabular}{llllll}
\hline \multirow{2}{*}{ Strain } & \multicolumn{2}{c}{ Use of $^{a}:$} & & \multicolumn{2}{c}{$\begin{array}{c}\text { Hybridization } \\
\text { with probe: }\end{array}$} \\
\cline { 2 - 3 } \cline { 5 - 6 } & $\begin{array}{c}\text { meso- } \\
\text { Erythritol }\end{array}$ & $\begin{array}{c}N \text {-Acetyl- } \\
\text { glucosamine }\end{array}$ & HR $\quad$ HS \\
\hline
\end{tabular}

\begin{tabular}{|c|c|c|c|c|}
\hline \multicolumn{5}{|c|}{ Herbaspirillum seropedicae } \\
\hline $\mathrm{Z} 67^{\frac{1}{\mathrm{~T}}}$ & - & + & - & + \\
\hline Z78 & - & + & - & + \\
\hline Z152 & - & + & - & + \\
\hline ZAS74 & - & + & - & + \\
\hline LMG $2284^{b}$ & - & + & - & + \\
\hline HRC 50 & - & + & - & + \\
\hline HRC 54 & - & + & - & + \\
\hline HCC 100 & - & + & - & + \\
\hline HCC 102 & - & + & - & + \\
\hline HCC 105 & - & + & - & + \\
\hline HPD 5 & - & + & - & + \\
\hline HRL brach. & - & + & - & + \\
\hline HRL digt. & - & + & - & + \\
\hline HRL gord. & - & + & - & + \\
\hline \multicolumn{5}{|c|}{ Herbaspirillum nubrisubalbicans } \\
\hline LMG $2286^{\mathrm{T}}$ & + & - & + & - \\
\hline HRC 51 & + & - & + & - \\
\hline HCC 103 & + & - & + & - \\
\hline HPD 1 & + & - & + & - \\
\hline LMG 1278 & + & - & + & - \\
\hline LMG 6420 & + & - & + & - \\
\hline IBSBF 175 & + & - & + & - \\
\hline IBSBF 198 & + & - & + & - \\
\hline B 4362 & + & - & + & - \\
\hline \multicolumn{5}{|c|}{ Herbaspirillum species 3} \\
\hline LMG 5523 & + & - & + & - \\
\hline LMG 5934 & $+(-)$ & - & + & - \\
\hline LMG 7680 & $+(-)$ & - & + & - \\
\hline LMG 2285 & + & - & + & - \\
\hline
\end{tabular}

${ }^{a}$ As tested by conventional tests and API $50 \mathrm{CH}$. When both systems did not give the same result, the API $50 \mathrm{CH}$ result is given in parentheses.

${ }^{b}$ This strain does not fix dinitrogen, as evaluated by ${ }^{15} \mathrm{~N}_{2}$ incorporation and $\mathrm{C}_{2} \mathrm{H}_{2}$ reduction.

optimum temperature for $\mathrm{N}_{2}$-dependent growth is $34^{\circ} \mathrm{C}$; no growth occurs at 22 and $38^{\circ} \mathrm{C}$. Starch and gelatin are not hydrolyzed. Good growth is observed between pH 5.3 and 8.0. Nitrate is assimilated or dissimilated or both to $\mathrm{NO}_{2}{ }^{-}$under $\mathrm{O}_{2}$ limitation. No $\mathrm{NO}_{3}{ }^{-}$-dependent anaerobic growth and no visible gas production from $\mathrm{NO}_{3}{ }^{-}$occur in solid or semisolid medium. The habitats are roots, stems and leaves of all kinds of members of the family Gramineae ( 13 species). Members of this species could not be isolated from soil, and when inoculated in large numbers into soil, they cannot be reisolated after 3 weeks, except when sorghum plants are introduced (26). $H$. seropedicae can be differentiated from the other species by its auxanographic features (Table 2) and by the use of the HS DNA probe.

The $\mathrm{G}+\mathrm{C}$ content of the DNA is 64 to $65 \%$.

The type strain is $\mathrm{Z} 67=\mathrm{ATCC} 35892=\mathrm{LMG} 6513$, with a $\mathrm{G}+\mathrm{C}$ content of $64.4 \mathrm{~mol} \%$.

Description of $\boldsymbol{H}$. rubrisubalbicans (Christopher and Edgerton 1930) comb. nov. (Pseudomonas rubrisubalbicans Approved Lists 1980) H. rubrisubalbicans (ru.bri. sub.al'bi.cans L. adj. ruber, red; L. adj. subalbicans, whitish; M.L. adj. rubrisubalbicans, red-whitish, referring to the symptoms of mottled stripe disease). The description is based on that of Palleroni et al. (28) for $[P$.$] rubrisubalbicans and the results of this study. The$ organism appears as slightly curved rods and is motile by means of several polar flagella. Poly- $\beta$-hydroxybutyrate is accumulated. Colonies on $2 \%$ glucose-peptone agar are mucoid (not in 2\% sucrose-peptone agar). No pigments are produced. Cells do not produce $\mathrm{H}_{2} \mathrm{~S}$. There is no hydrolysis of gelatin, starch, and Tween 80 . Most strains reduce nitrate to nitrite. Denitrification is negative. Growth occurs at $40^{\circ} \mathrm{C}$; the optimal temperature for growth is $30^{\circ} \mathrm{C}$. Auxanographic differences from the other Herbaspirillum species are given in Table 2.

Acid is produced from glucose, fructose, galactose, arabinose, mannitol, lactose, glycerol, and sorbitol. No acid is produced from sucrose, raffinose, salicin, maltose, cellobiose, or meso-inositol. Cells do fix $\mathrm{N}_{2}$ as efficiently as $H$. seropedicae. The organism causes mottled stripe disease on sugarcane, mainly on plant genotypes from regions in which high- $\mathrm{N}$ fertilizer applications were used. $H$. rubrisubalbicans has now been shown to grow abundantly in nitrogen-free semisolid media, with veil-like pellicles, just as $H$. seropedicae does. Nitrogenase activities and efficiency in biological $\mathrm{N}_{2}$ fixation are the same as those of $H$. seropedicae. In contrast to this species, its occurrence seems limited to sugarcane, but when artificially inoculated by injection, red stripes are also formed on Sorghum vulgare and Pennisetum purpureum (29). It also could be reisolated from these plants. The optimal growth temperature is $30^{\circ} \mathrm{C}$, in contrast to $34^{\circ} \mathrm{C}$ for $H$. seropedicae.

The $\mathrm{G}+\mathrm{C}$ content of the DNA is 62 to $63 \%$.

The type strain is NCPPB $1027=\mathrm{LMG} 2286$. Its $\mathrm{G}+\mathrm{C}$ content is $62.5 \%$.

Herbaspirillum species 3 combines isolates from various different origins with high levels of DNA relatedness among them, but it is clearly distinguishable from the two species described and is unable to fix dinitrogen. The detailed description of this species will be given elsewhere (14). For additional characteristics of this species, see Table 2.

\section{ACKNOWLEDGMENTS}

M.G. and K.K. are indebted to the Nationaal Fonds voor Geneeskundig Onderzoek for research and personnel grants. We are grateful to D. Monget, bioMérieux, Montalieu-Vercieu, France, for supplying API auxanographic galleries.

Part of the research carried out by the Brazilian and German scientists was supported by project ENV 34, CNPg/IBAMA/BMFT.

\section{REFERENCES}

1. Baldani, J. I. Unpublished data.

2. Baldani, J. I., V. L. D. Baldani, M. J. A. M. Sampaio, and J. Döbereiner. 1984. A fourth Azospirillum species from cereal roots. An. Acad. Bras. Cienc. 56:365.

3. Baldani, J. I., V. L. D. Baldani, L. Seldin, and J. Döbereiner. 1986. Characterization of Herbaspinillum seropedicae gen. nov., sp. nov., a root-associated nitrogen-fixing bacterium. Int. J. Syst. Bacteriol. 36:86-93.

4. Baldani, V. L. D., J. I. Baldani, F. Olivares, and J. Döbereiner. 1992. Identification and ecology of Herbaspirillum seropedicae and the closely related Pseudomonas rubrisubalbicans. Symbiosis 13:65-73.

5. De Ley, J. 1970. Reexamination of the association between melting point, buoyant density, and chemical base composition of deoxyribonucleic acid. $\mathbf{J}$. Bacteriol. 101:738-754.

6. De Ley, J. 1992. The Proteobacteria: ribosomal RNA cistron similarities and bacterial taxonomy, p. 2111-2140. In A. Balows, H. G. Trüper, M. Dworkin, W. Harder, and K.-H. Schleifer (ed.), The prokaryotes, 2nd ed., vol. II Springer-Verlag, New York.

7. De Ley, J., H. Cattoir, and A. Reynaerts. 1970. The quantitative measurement of DNA hybridization from renaturation rates. Eur. J. Biochem. 12: $133-142$.

8. De Ley, J., and J. De Smedt. 1975. Improvements of the membrane filter method for DNA:rRNA hybridization. Antonie Leeuwenhoek. J. Microbiol. Serol. 41:287-307.

9. De Ley, J., and J. Van Muylem. 1963. Some application of deoxyribonucleic 
acid base composition in bacterial taxonomy. Antonie Leeuwenhoek. J. Microbiol. Serol. 29:344-358.

10. Döbereiner, J. 1980. Forage grasses and grain crops, p. 535-555. In F. J. Bergersen (ed.), Methods for evaluating biological nitrogen fixation. John Wiley \& Sons, Chichester, United Kingdom.

11. Döbereiner, J. 1992. Recent changes in concepts of plant bacteria interactions: endophytic $\mathrm{N}_{2}$ fixing bacteria. Cienc. Cult. 44:310-313.

12. Falk, E. C., J. L. Johnson, V. L. D. Baldani, J. Döbereiner, and N. R. Krieg. 1986. Deoxyribonucleic and ribonucleic acid homology studies of the genera Azospirillum and Conglomeromonas. Int. J. Syst. Bacteriol. 36:80-85.

13. Falsen, E. 1996. Catalogue of strains, CCUG Culture Collection, 5th ed. University of Göteborg, Göteborg, Sweden.

14. Gillis, M. Unpublished observations.

15. Gillis, M., and J. De Ley. 1992. The genera Chromobacterium and Janthinobacterium, p. 2591-2600, In A. Balows, H. Trüper, M. Dworkin, W. Harder, and K.-H. Schleifer (ed.), The prokaryotes, 2nd ed., vol. III. Springer-Verlag, New York

16. Gillis, M., J. Döbereiner, B. Pot, M. Goor, E. Falsen, B. Hoste, B. Reinhold, and K. Kersters. 1990. Taxonomic relationships between Pseudomonas rubrisubalbicans, some misnamed clinical isolates (EF group 1) and Herbaspirillum seropedicae, p. 293-294, In M. Polsinelli, R. Materassi, and M. Vincenzini (ed.), Nitrogen fixation. Kluwer Academic Publisher, Dordrecht, The Netherlands.

17. Gillis, M., T. V. Van, R. Bardin, M. Goor, P. Hebbar, A. Willems, P. Segers, K. Kersters, T. Heulin, and M. P. Fernandez. 1995. Polyphasic taxonomy in the genus Burkholderia leading to an emended description of the genus and proposition of Burkholderia vietnamiensis sp. nov. for $\mathrm{N}_{2}$-fixing isolates from rice in Vietnam. Int. J. Syst. Bacteriol. 45:274-289.

18. Hale, C. N., and J. P. Wilke. 1972. A comparative study of Pseudomonas species pathogenic to sorghum. N. Z. J. Agric. Res. 15:448-456.

19. Höpfl, P., W. Ludwig, K-H. Schleifer, and N. Larsen. 1989. The 23S ribosomal RNA higher-order structure of Pseudomonas cepacia and other prokaryotes. Eur. J. Biochem. 185:355-364.

20. Kersters, K., K.-H. Hinz, A. Hertle, P. Segers, A. Lievens, O. Siegmann, and J. De Ley. 1984. Bordetella avium sp. nov., isolated from the respiratory tracts of turkeys and other birds. Int. J. Syst. Bacteriol. 34:56-70.

21. Kirchhof, G., and A. Hartmann. 1992. Development of gene probes for Azospirillum based on 23S-rRNA sequences. Symbiosis 13:27-35.

22. Lapage, S. P., P. H. A. Sneath, E. F. Lessel, V. B. D. Skerman, H. P. R Seeliger, and W. A. Clark (ed.). 1992. International code of nomenclature of bacteria (1990 revision). American Society for Microbiology, Washington, D.C.

23. Marmur, J. 1961. A procedure for the isolation of deoxyribonucleic acid from microorganisms. J. Mol. Biol. 3:208-218.

24. Marmur, J., and P. Doty. 1962. Determination of the base composition of deoxyribonucleic acid from its thermal denaturation temperature. J. Mol. Biol. 5:109-118.
25. Oelmuller, U., N. Krüger, A. Steinbüchel, and C. G. Friedrich. 1990. Isolation of prokaryotic RNA and detection of specific mRNA with biotinylated probes. J. Microbiol. Methods 11:73-84.

26. Olivares, F. L. Unpublished observations

27. Olivares, F. L., V. L. D. Baldani, V. M. Reis, J. I. Baldani, and J. Döbereiner. 1993. Ecology of the endophytic diazotrophicus Herbaspirillum spp. Fitopatol. Bras. 18(Suppl.):289.

28. Palleroni, N. J. 1984. Genus I Pseudomonas Migula $1894,237^{\mathrm{AL}}$, p. 141-199. In N. R. Krieg and J. G. Holt (ed.), Bergey's manual of systematic bacteriology, vol. 1. Williams \& Wilkins, Baltimore.

29. Pimentel, J. P., F. Olivares, R. M. Pitard, S. Urquiaga, F. Akiba, and J. Döbereiner. 1991. Dinitrogen fixation and infection of grass leaves by Pseudomonas rubrisubalbicans and Herbaspirillum seropedicae. Plant soil 137: 61-65.

30. Pot, B., M. Gillis, and J. De Ley. 1992. The genus Aquaspirillum, p. 2569 2582. In A. Balows, H. G. Trüper, M. Dworkin, W. Harder, and K.-H Schleifer (ed.), The prokaryotes, 2nd ed., vol. III. Springer-Verlag, New York.

31. Skerman, V. B. D., V. McGowan, and P. H. A. Sneath (ed.). 1980. Approved lists of bacterial names. American Society for Microbiology, Washington, D.C.

32. Sneath, P. H. A. 1984. Janthinobacterium De Ley, Segers and Gillis 1978 , $164^{\text {AL }}$, p. 376-377. In N. R. Krieg and J. G. Holt (ed.), Bergey's manual of systematic bacteriology, vol. 1. Williams \& Wilkins, Baltimore.

33. Sneath, P. H. A., and R. R. Sokal. 1973. Numerical taxonomy. The principles and practice of numerical classification. W. H. Freeman and Co., San Francisco.

34. Stackebrandt, E., R. G. E. Murray, and H. G. Trüper. 1988. Proteobacteria classis nov., a name for the phylogenetic taxon that includes the "purple bacteria and their relatives." Int. J. Syst. Bacteriol. 38:321-325.

35. Vandamme, P., M. Vancanneyt, B. Pot, L. Mels, B. Hoste, D. Dewettinck, L. Vlaes, C. Van Den Borre, R. Higgins, J. Hommez, K. Kersters, J.-P. Butzler, and H. Goossens. 1992. Polyphasic taxonomic study of the emended genus Arcobacter with Arcobacter butzleri comb. nov. and Arcobacter skirrowii sp. nov., an aerotolerant bacterium isolated from veterinary specimens. Int. J. Syst. Bacteriol. 42:344-356.

36. Van Landschoot, A., and J. De Ley. 1983. Intra- and intergeneric similarities of the rRNA cistrons of Alteromonas, Marinomonas (gen. nov.) and some other gram-negative bacteria. J. Gen. Microbiol. 129:3057-3074.

37. Wayne, L. G., D. J. Brenner, R. R. Colwell, P. A. D. Grimont, O. Kandler, M. I. Krichevsky, L. H. Moore, W. E. C. Moore, R. G. E. Murray, E. Stackebrandt, M. P. Starr, and H. G. Trüper. 1987. Report of the Ad Hoc Committee on Reconciliation of Approaches to Bacterial Systematics. Int. J. Syst. Bacteriol. 37:463-464.

38. Wishart, D. 1978. Clustan user manual, 3rd ed. Inter-University Research Councils Series, report no. 47. Program Library Unit, Edinburgh University, Edinburgh. 